\title{
The use of direct immunofluorescence and nested polymerase chain reaction in diagnosing perinatal infections of Chlamydia trachomatis
}

\author{
Magdalena Frej-Mądrzak ${ }^{1, A-D}$, Dorota Teryks-Wołyniec ${ }^{1, B, C}$, Piotr Jankowski ${ }^{2, A, B}$, Paulina Krochmal ${ }^{1, C, D}$, \\ Jolanta Sarowska ${ }^{1, E}$, Agnieszka Jama-Kmiecik ${ }^{1, E}$, Irena Choroszy-Król ${ }^{1, A, E, F}$ \\ ${ }^{1}$ Department of Basic Sciences, Faculty of Health Sciences, Wroclaw Medical University, Poland \\ $21^{\text {st }}$ Department and Clinic of Gynecology and Obstetrics, Faculty of Medicine, Wroclaw Medical University, Poland \\ A - research concept and design; B - collection and/or assembly of data; C - data analysis and interpretation; \\ $D$ - writing the article; $E$ - critical revision of the article; $F$ - final approval of the article
}

Address for correspondence

Magdalena Frej-Mądrzak

E-mail: magdalena.frej-madrzak@umed.wroc.pl

Funding sources

None declared

Conflict of interest

None declared

Received on February 7, 2016

Reviewed on September 19, 2016

Accepted on July 6, 2017

\begin{abstract}
Background. Chlamydia infection is the most frequently reported infectious, sexually transmitted disease (STD). Generally, Chlamydia trachomatis (C. trachomatis) infection of neonates is the result of perinatal exposure to the mother's infected cervix.

Objectives. The aim of the study was to estimate the frequency of infection caused by C. trachomatis in newborn infants. In this study of C. trachomatis perinatal infection, 107 infants born at the Wroclaw Medical University Clinic of Gynecology and Obstetrics (Poland) were tested to investigate whether C. trachomatis was present in swabs taken from the eyes and throats of children.
\end{abstract}

Material and methods. Each specimen was tested using the direct immunofluorescence test (DIF) and the nested polymerase chain reaction (PCR) method.

Results. The presence of C. trachomatis, irrespective of the origin of the swabs (ocular or from the throat), was confirmed in 62 newborns, amounting to 57.6\% of the tested population. The occurrence of C. trachomatis in ocular swabs was confirmed in 35 children (32.7\%). In the material taken from the throat, there were 48 newborns considered chlamydia-positive (44.9\%). In the specimens taken from both the ocular and pharyngeal locations, there was a higher proportion of positive results while using the nested-PCR method in comparison to the DIF test. The specificity of the DIF method with reference to the nested-PCR was $67.9 \%$ for ocular swabs. In the material taken from the throat, the sensitivity of the DIF method with reference to the nested-PCR was $75.0 \%$ and the specificity was $62.1 \%$.

Conclusions. Because of the importance of perinatal infections, it is recommended to perform a study among a larger group of patients in order to gain more reliable results.

Key words: Chlamydia trachomatis, infection, newborn

DOI

10.17219/acem/75724

\section{Copyright}

Copyright by Author(s)

This is an article distributed under the terms of the

Creative Commons Attribution Non-Commercial License

(http://creativecommons.org/licenses/by-nc-nd/4.0/) 


\section{Introduction}

Infections of Chlamydia trachomatis (C. trachomatis), caused by oculogenital serotypes D-K, are among the most common sexually transmitted diseases (STDs). It is estimated that there are approx. 100 million new cases of C. trachomatis infection every year worldwide. ${ }^{1}$ As long as chlamydia is the most commonly reported STD in the United States, it is recommended that annual screening examinations are carried out there in sexually active women under the age of 25 years, or in older women who are at an increased risk of infection..$^{2-4}$ Moreover, it is suggested that pregnant women in this age group undergo testing for C. trachomatis during their $3^{\text {rd }}$ trimester of pregnancy. ${ }^{4}$

The oculogenital serovars (D-K) of C. trachomatis in newborn infants may be responsible for developing conjunctivitis and interstitial pneumonia, with conjunctivitis occurring more frequently. These include perinatal infections that take place during the passage of the newborn infant through the infected mother's cervix. ${ }^{5,6}$ However, 1 case of $C$. trachomatis conjunctivitis was reported in a newborn infant delivered by cesarean section, which argues in favor of intrauterine infection by the continuity of tissues. ${ }^{6}$ The risk of $C$. trachomatis perinatal infection in newborn infants is estimated at approx. $30 \% .^{5}$

A chlamydial etiology should be considered if the mother was infected in the past. Neonatal conjunctivitis occurs in $18-50 \%$ of children of infected mothers, with frequent occurrence in preterm infants, who are at risk, since chlamydia infections may cause premature labor. ${ }^{7}$ The infection develops up to 3 weeks after birth and may become chronic. Its characteristic symptoms include mucopurulent discharge from the conjunctival sac with accompanying swelling and redness, but the infection can also be asymptomatic. Conjunctivitis, if left untreated, may lead to blindness. ${ }^{8}$

Chlamydia trachomatis conjunctivitis and pneumonia coexist in up to $1 / 2$ of ill newborn infants. Interstitial pneumonia develops between the $3^{\text {rd }}$ and the $12^{\text {th }}$ week of age, and can vary in intensity. In most cases, the disease is mild, but breathing disorders may at times require oxygen therapy. High levels of eosinophils can be reported in the blood. A large number of B lymphocytes and plasma cells in the blood, which is characteristic for C. trachomatis pneumonia, results in high levels of immunoglobulin $M$ (IgM) antibodies in the blood. The changes can be seen in spirometry and in radiological examination. The symptoms include a dry cough, a low-grade fever and rapid breathing. ${ }^{6,7,9}$ It is suspected that $C$. trachomatis infection may be related to sudden infant death syndrome (SIDS). ${ }^{7,10}$

Infrequently, C. trachomatis in newborn infants can cause infections of the vagina, rectum, nasopharynx, or middle ear.

\section{Aim of the study}

The aim of the study was to estimate the frequency of infection caused by $C$. trachomatis in newborn infants.

\section{Material and methods}

The experimental material consisted of swabs collected from newborn infants at the $1^{\text {st }}$ Department and Clinic of Gynecology and Obstetrics (Wroclaw Medical University, Poland). A total of 109 children were tested. Four swabs were collected from every newborn infant: 2 from the eye and 2 from the throat. We used a direct immunofluorescence test (DIF) - Chlamydia Pathfinder (Bio-Rad Laboratories, Marnes-la-Coquette, France) and the nested polymerase chain reaction technique (nested-PCR) - PCR-Chlamydia trachomatis test (DNA Gdańsk, Poland) in order to detect chlamydia infection. Two hundred and eighteen tests were conducted by DIF (109 eye swabs and 109 throat swabs), and the same number of tests was done by nested-PCR. All tests were performed in the Chlamydia Research Laboratory, Department of Basic Sciences, Wroclaw Medical University, Poland.

The quality of the tested material is of great diagnostic importance in the case of $C$. trachomatis. Due to the fact that chlamydiae are obligate intracellular parasites, the obtained material must contain epithelial cells. Detecting bacteria in the absence of epithelial cells provides unreliable results. Neither eye fluid nor saliva constitute suitable test material.

Since epithelium was not detected in the swabs taken from 2 patients, we did not take into account the results from these samples. Altogether, we analyzed 428 results.

The swabs were collected by authorized personnel in accordance with the appropriate procedures.

The analysis of results was performed using the statistical package PQStat v. 1.6.0.428 (PQStat Software, Poznań, Poland).

Comparing the results of the eye swabs to those of the throat swabs, the measure of compliance was applied. Comparing the results of the DIF method in reference to the gold standard - the PCR method - the results of compliance, sensitivity, specificity, and positive and negative predictive value were specified, and 95\% confidence intervals (CI) were estimated for these results. Compliance measurements were also analyzed with McNemar's test.

A probability of $\mathrm{p}<0.05$ was determined to be significant and a level of $\mathrm{p}<0.01$ was determined to be highly significant.

\section{Results}

We found chlamydia in both the eye and throat in $19.6 \%$ of all newborn infants (21 patients). Chlamydia was not detected at all in $42.1 \%$ of newborn infants (45 patients).

In the material taken from both the eye and throat, there was a significantly higher percentage of positive results obtained by nested-PCR (34/107 for the eye, 45/107 for the throat) than by DIF (1/107 for the eye; $12 / 107$ for the throat) (Table 1). 
Table 1. Test results for the presence of Chlamydia trachomatis by the method used and the source location of the sample

\begin{tabular}{|l|c|c|}
\hline \multirow{2}{*}{ Sample type } & Number of samples & Positive results \\
\cline { 3 - 3 } \multicolumn{1}{|c|}{ DIF - eye } & 107 & $\mathrm{n}$ \\
\hline DIF - throat & 107 & 1 \\
\hline Nested-PCR - eye & 107 & 12 \\
\hline Nested-PCR - throat & 107 & 34 \\
\hline
\end{tabular}

DIF - direct immunofluorescence test; PCR - polymerase chain reaction.

The presence of C. trachomatis in eye swabs was reported in 35 newborns, i.e., in $32.7 \%$ of patients. There was only 1 positive result in DIF. In this sample, the nestedPCR results were negative, which is equivalent to the lack of consistently positive results in eye swabs. We reported 72 consistently negative results $(68.2 \%)$ and 35 inconsistently negative results $(32.7 \%)$ (Table 2$)$.

Table 2. Consistency of results obtained by nested-PCR and DIF

\begin{tabular}{|l|c|c|c|c|c|c|}
\multirow{2}{*}{$\begin{array}{c}\text { Sample } \\
\text { type }\end{array}$} & $\begin{array}{c}\text { Number } \\
\text { of samples }\end{array}$ & \multicolumn{2}{|c|}{$\begin{array}{c}\text { Consistent } \\
\text { positive } \\
\text { results }\end{array}$} & \multicolumn{2}{c|}{$\begin{array}{c}\text { Consistent } \\
\text { negative } \\
\text { results }\end{array}$} & $\begin{array}{c}\text { Inconsistent } \\
\text { results }\end{array}$ \\
\cline { 3 - 7 } & $\mathrm{n}$ & $\%$ & $\mathrm{n}$ & $\%$ & $\mathrm{n}$ \\
\hline Eye & 107 & 0 & 0.0 & 72 & 67.3 & 35 \\
\hline Throat & 107 & 9 & 8.4 & 59 & 55.1 & 39 \\
\hline
\end{tabular}

DIF - direct immunofluorescence test; PCR - polymerase chain reaction.

We detected C. trachomatis in throat swabs of 48 newborns (44.9\%). Consistently positive results were obtained from 9 patients $(8.4 \%)$, whereas consistently negative results were found in 59 patients (55.1\%). There were $36.4 \%$ of inconsistent results (39 patients) (Table 2).

In the medical interview, the respondents reported the occurrence of additional factors that could increase the likelihood of neonatal chlamydia. Newborn infants without such additional factors accounted for $57.0 \%$ of all patients (61 patients). We isolated several groups on the basis of a history of diabetes in the mother or the occurrence of specific symptoms accompanying chlamydia infection in the child (or even previously confirmed C. trachomatis infection). Among participants with no family history, chlamydia was reported in 36 patients (33.6\%).

In the medical interview, 17 mothers of newborn infants (15.9\%) who were tested during pregnancy or before pregnancy reported previous $C$. trachomatis infection. Chlamydia was detected in newborns in $23.5 \%$ of cases, whereas in 3 out of 4 cases, positive results were obtained from both the eye and throat, but only by nested-PCR (Table 3 ).

We reported symptoms of respiratory tract infections in 7 newborn infants, including $42.9 \%$ (3 newborns) with positive nested-PCR results taken from the throat, and in 1 case - from the eye. In 3 newborns, we did not report C. trachomatis in either the eye or throat.
Table 3. The presence of the risk factors of Chlamydia trachomatis infection in the tested material and the incidence of positive results

\begin{tabular}{|l|c|c|}
\multicolumn{1}{|c|}{ Risk factor } & $\begin{array}{c}\text { Number } \\
\text { of samples }\end{array}$ & $\begin{array}{c}\text { Positive } \\
\text { results }\end{array}$ \\
\cline { 2 - 3 } & $\mathrm{n}$ & $\mathrm{n}$ \\
\hline $\begin{array}{l}\text { Presence of C. trachomatis infection } \\
\text { in the mother }\end{array}$ & 17 & 4 \\
\hline Symptoms of the respiratory system & 7 & 4 \\
\hline Symptoms of the eye & 6 & 4 \\
\hline Check tests & 16 & 9 \\
\hline Lack of load & 61 & 36 \\
\hline
\end{tabular}

In 6 newborn infants, we reported symptoms related to eye infection, whereas in 3 newborns (50.0\%), we reported positive results from the eye, and in 1 case from the throat alone. In 2 patients, we found negative results despite the occurrence of symptoms.

In patients with eye or respiratory symptoms, we obtained positive results mainly by nested-PCR. In most of these cases, in both the throat and eye, DIF testing gave negative results (in all 6 newborns with ocular symptoms and in 6 out of 7 newborns with respiratory symptoms).

We carried out a follow-up examination in 16 newborn infants (15.0\%). Chlamydia trachomatis was confirmed in 9 cases $(56.3 \%)$ by nested-PCR, while there were no positive DIF results.

The compatibility (accuracy) of diagnosis for both methods equaled $87.85 \%$ (95\% CI $=80.12-93.37 \%)$, which refers only to the "negative" results. However, in any case, the "positive" results were not consistent in both measurements. This is mainly due to the fact that the DIF method for eye swabs showed only 1 positive result. Among the results obtained by the DIF method for the throat, 12 positive results were reported. The results of McNemar's compliance test indicated a significantly high level of inconsistency of the results for both measurements $\left(\chi^{2}=7.69\right.$; degree of freedom $(\mathrm{df})=1 ; \mathrm{p}=0.0055)$ (Table 4).

The compatibility (accuracy) of diagnosis for both methods equaled $65.42 \%(95 \% \mathrm{CI}=55.61-74.35 \%)$, and this result is the sum of consistent negative results $(45.79 \%)$ and consistent positive results (19.63\%). The results of McNemar's compliance test indicated an insignificant level of differences in both measurements $\left(X^{2}=2.70\right.$; $\mathrm{df}=1$; $p=0.1002)$, so both measurements can be considered compatible (Table 5).

The compatibility (accuracy) of diagnosis for both methods equaled $67.29 \%$ (95\% CI $=57.54-76.05 \%)$, which refers only to the "negative" results. However, in any case, the "positive" results were not consistent in both measurements. This is mainly due to the fact that the DIF method for the eye swabs showed only 1 positive result. Among the results obtained by the PCR method for the eye, there were 34 positive results. Accordingly, the sensitivity of the DIF method for the eye compared to the PCR method for the eye equaled $0 \%$; the specificity equaled $98.63 \%$ 
Table 4. Summary of the results of DIF - eye and DIF - throat

\begin{tabular}{|c|c|c|c|c|c|}
\hline \multirow{2}{*}{\multicolumn{3}{|c|}{$\begin{array}{l}\text { Results of DIF - eye } \\
\text { and DIF - throat }\end{array}$}} & \multicolumn{2}{|c|}{ DIF - throat } & \multirow{2}{*}{ Total } \\
\hline & & & 1 & 0 & \\
\hline \multirow{8}{*}{ DIF - eye } & \multirow{4}{*}{1} & quantity (n) & 0 & 1 & 1 \\
\hline & & $\%$ of line & 0 & 100 & - \\
\hline & & $\%$ of column & 0 & 1.05 & - \\
\hline & & $\%$ of total & 0 & 0.93 & 0.935 \\
\hline & \multirow{4}{*}{0} & quantity (n) & 12 & 94 & 106 \\
\hline & & $\%$ of line & 11.32 & 88.68 & - \\
\hline & & $\%$ of column & 100 & 98.95 & - \\
\hline & & $\%$ of total & 11.21 & 87.85 & 99.065 \\
\hline \multirow{2}{*}{\multicolumn{2}{|c|}{ Total }} & quantity (n) & 12 & 95 & 107 \\
\hline & & $\%$ of total & 11.215 & 88.785 & 100 \\
\hline
\end{tabular}

DIF - direct immunofluorescence test.

Table 5. Summary of the results of PCR - eye and PCR - throat

\begin{tabular}{|c|c|c|c|c|c|}
\hline \multirow{2}{*}{\multicolumn{3}{|c|}{$\begin{array}{l}\text { Results of PCR - eye } \\
\text { and PCR - throat }\end{array}$}} & \multicolumn{2}{|c|}{ PCR - throat } & \multirow{3}{*}{$\begin{array}{l}\text { Total } \\
34\end{array}$} \\
\hline & & & 1 & 0 & \\
\hline \multirow{8}{*}{ PCR - eye } & \multirow{4}{*}{1} & quantity (n) & 21 & 13 & \\
\hline & & $\%$ of line & 61.76 & 38.24 & - \\
\hline & & $\%$ of column & 46.67 & 20.97 & - \\
\hline & & $\%$ of total & 19.63 & 12.15 & 31.776 \\
\hline & \multirow{4}{*}{0} & quantity (n) & 24 & 49 & 73 \\
\hline & & $\%$ of line & 32.88 & 67.12 & - \\
\hline & & $\%$ of column & 53.33 & 79.03 & - \\
\hline & & $\%$ of total & 22.43 & 45.79 & 68.224 \\
\hline \multirow{2}{*}{\multicolumn{2}{|c|}{ Total }} & quantity (n) & 45 & 62 & 107 \\
\hline & & $\%$ of total & 42.056 & 57.944 & 100 \\
\hline
\end{tabular}

PCR - polymerase chain reaction.

(95\% CI = 92.60-99.96\%). The positive predictive value was $0 \%$ and the negative predictive value was $67.92 \%$ (95\% CI = 58.16-76.66\%). The results of McNemar's compliance test indicated a significantly high lack of consistency of results for both measurements $\left(x^{2}=29.26\right.$; $\left.d f=1 ; p<0.0001\right)$.

The compatibility (accuracy) of diagnosis for both methods equaled $63.55 \%$ (95\% CI $=53.69-72.64 \%)$, and this result is the sum of consistent negative results $(55.14 \%)$ and consistent positive results (8.41\%). The sensitivity of the DIF method for throat swabs comparing to the reference method (PCR) was $20 \%(95 \% \mathrm{CI}=9.58-34.60 \%)$ and the specificity was $95.16 \%$ (95\% CI $=86.50-98.99 \%)$. The positive predictive value was $75 \%(95 \% \mathrm{CI}=42.81-94.51 \%)$ and the negative predictive value was $62.10 \%(95 \% \mathrm{CI}=$ 51.57-71.86\%). The results of McNemar's compliance test indicated a significantly high lack of consistency of results for both measurements $\left(x^{2}=26.26 ; \mathrm{df}=1 ; \mathrm{p}<0.0001\right)$ (Table 7). When testing the sensitivity and specificity, PCR and DIF methods were compared, the compliance of positive and negative results obtained with these methods in the same patients.
Table 6. Summary of the results of DIF - eye and PCR - eye

\begin{tabular}{|c|c|c|c|c|c|}
\hline \multirow{2}{*}{\multicolumn{3}{|c|}{$\begin{array}{l}\text { Results of DIF - eye } \\
\text { and PCR - eye }\end{array}$}} & \multicolumn{2}{|c|}{ PCR - eye } & \multirow{3}{*}{$\begin{array}{c}\text { Total } \\
1\end{array}$} \\
\hline & & & \multirow{2}{*}{$\begin{array}{l}1 \\
0\end{array}$} & \multirow{2}{*}{$\begin{array}{l}0 \\
1\end{array}$} & \\
\hline \multirow{8}{*}{ DIF - eye } & \multirow{4}{*}{1} & quantity (n) & & & \\
\hline & & $\%$ of line & 0 & 100 & - \\
\hline & & $\%$ of column & 0 & 1.37 & - \\
\hline & & $\%$ of total & 0 & 0.93 & 0.935 \\
\hline & \multirow{4}{*}{0} & quantity (n) & 34 & 72 & 106 \\
\hline & & $\%$ of line & 32.08 & 67.92 & - \\
\hline & & $\%$ of column & 100 & 98.63 & - \\
\hline & & $\%$ of total & 31.78 & 67.29 & 99.065 \\
\hline \multirow{2}{*}{\multicolumn{2}{|c|}{ Total }} & quantity (n) & 34 & 73 & 107 \\
\hline & & $\%$ of total & 31.776 & 68.224 & 100 \\
\hline
\end{tabular}

DIF - direct immunofluorescence test; PCR - polymerase chain reaction.

Table 7. Summary of the results of DIF - throat and PCR - throat

\begin{tabular}{|c|c|c|c|c|c|}
\hline \multirow{2}{*}{\multicolumn{3}{|c|}{$\begin{array}{l}\text { Results of DIF - eye } \\
\text { and PCR - throat }\end{array}$}} & \multicolumn{2}{|c|}{ PCR - throat } & \multirow{3}{*}{$\begin{array}{c}\text { Total } \\
12\end{array}$} \\
\hline & & & 1 & 0 & \\
\hline \multirow{8}{*}{ DIF - throat } & \multirow{4}{*}{1} & quantity (n) & 9 & 3 & \\
\hline & & $\%$ of line & 75 & 25 & - \\
\hline & & $\%$ of column & 20 & 4.84 & - \\
\hline & & $\%$ of total & 8.41 & 2.8 & 11.215 \\
\hline & \multirow{4}{*}{0} & quantity (n) & 36 & 59 & 95 \\
\hline & & $\%$ of line & 37.89 & 62.11 & - \\
\hline & & $\%$ of column & 80 & 95.16 & - \\
\hline & & $\%$ of total & 33.64 & 55.14 & 88.785 \\
\hline \multirow{2}{*}{\multicolumn{2}{|c|}{ Total }} & quantity (n) & 45 & 62 & 107 \\
\hline & & $\%$ of total & 42.056 & 57.944 & 100 \\
\hline
\end{tabular}

DIF - direct immunofluorescence test; PCR - polymerase chain reaction.

\section{Discussion}

Researchers rarely raise the subject of the occurrence of $C$. trachomatis in newborn infants, but studies carried out on newborn infants born to healthy mothers are even less frequent. This may result from the fact that conjunctivitis, the most common form of chlamydia in newborn infants, usually presents mild symptoms and can resolve spontaneously. Another reason may be associated with the reluctance of some parents to take material from their children if there is no such need. Swabs, washes or aspirates from the nasopharynx and eyes are commonly used in diagnosing C. trachomatis infections in children. Competent eye or throat swabbing, even if it causes the child's discomfort, is necessary to achieve research reliability.

In 2012 and 2013, in order to diagnose perinatal infections, Frej-Mądrzak et al. examined the material collected from 55 children. ${ }^{11}$ The authors chose DIF as the research technique. The material included 33 eye swabs, 19 throat swabs and 11 urethra swabs. The authors reported 1 positive result in the throat swab (1.8\%). 
In Buenos Aires, between July 1995 and December 1998, Di Bartolomeo et al. examined 332 newborns diagnosed with conjunctivitis. ${ }^{12}$ The chosen method of research was the enzyme-linked immunosorbent assay (ELISA) technique. Positive results were confirmed by nested-PCR. The authors detected C. trachomatis in $7.8 \%$ of cases, which was the only pathogen detected in 22 out of 26 children. The authors detected other bacteria in 4 cases, but they did not have any significance as to the type of infection. The authors reported decreased occurrence of chlamydial conjunctivitis throughout the study period; in 1995 , this number amounted to 4.4 cases per 1,000 live births, and in 1998 to only 0.8 cases per 1,000 live births.

In studies carried out in Iran from 2007 to 2008 in a group of 223 newborn infants with symptoms of conjunctivitis, the authors confirmed positive results with the ELISA study method and by the indirect immunofluorescence test. ${ }^{13}$ There were 22 newborn infants, representing $13.6 \%$ of the whole study group, who tested positive for IgM against C. trachomatis. The authors reported bacteria in $8.0 \%$ of patients (18 of 223 newborns) in the confirmation test.

Bekler et al. conducted a study in a group of 56 newborns, including 35 premature and 21 term-born infants. ${ }^{14}$ The authors applied the DIF method and cultured the cell samples shortly after birth. Additionally, in the $2^{\text {nd }}$ and $6^{\text {th }}$ week of age, the authors examined the sera for immunoglobulin A (IgA) and IgM class antibodies with ELISA. Neither method revealed the presence of C. trachomatis in term-born children. In premature infants, the bacteria were reported in the throat of 10 out of 35 children (28.6\%).

In a group infected with $C$. trachomatis, a higher prevalence of conjunctivitis (60.0\% compared to $24.0 \%$ in healthy subjects) was reported. Similarly, a lower prevalence of conjunctivitis was observed in the children of healthy mothers (14-18.3\% compared to $45-47 \%$ in infected mothers). Neonatal pneumonia did not develop in the study groups. The DIF sensitivity amounted to $40.0 \%$, i.e., much lower than the sensitivity of the cell culture method (70.0\%).

Yu et al. examined 300 pregnant women and 305 newborns using the nested-PCR method. ${ }^{15}$ The test material taken from the women consisted of cervical swabs, and nasopharyngeal swabs were taken from the newborn infants. In the group of pregnant women, the authors reported positive test results in $11.0 \%$ of cases. In $24.2 \%$ of children of infected mothers (8 out of 33 newborns), the authors detected the presence of $C$. trachomatis in nasopharyngeal swabs. It should be noted, however, that 2 newborns with positive test results were born by cesarean section.

In our own research, which studied newborn infants at the $1^{\text {st }}$ Department and Clinic of Gynecology and Obstetrics of Wroclaw Medical University, we reported a very high percentage of patients (57.9\%) with positive laboratory test results for $C$. trachomatis.

When analyzing the test results from throat and eye swabs, we noted that chlamydiae were slightly more frequently detected in the throat. We reported that $C$. trachomatis was found more frequently by nestedPCR than by DIF.

At the time of carrying out this review, we did not find any new data on the subject regarding simultaneous examination of throat and eye swabs with the same research techniques. Therefore, we found it difficult to refer to individual authors.

Considering the importance of this subject, we suggest conducting studies on a larger group of patients in order to draw statistically relevant conclusions.

\section{Conclusions}

The detection of 48 cases of $C$. trachomatis infection in swabs from the throat and 35 cases in swabs from the eye by the PCR method suggests that tests detecting C. trachomatis in pregnant women should be included in routine diagnosis before giving birth. These examinations should be applied also to newborns whose mothers were diagnosed with chlamydia in the past in order to avoid the complications of perinatal infection by this pathogen.

In summary, the results obtained by the DIF method are not compatible with the reference results obtained by the PCR method. The DIF method is not diagnostically reliable.

\section{References}

1. World Health Organization. Baseline report on global sexually transmitted infection surveillance. WHO; 2012. http://www.who.int/reproductivehealth/publications/rtis/9789241505895/en/.

2. Centers for Disease Control and Prevention. Sexually Transmitted Disease Surveillance 2013. Atlanta, GA: Department of Health and Human Services; 2014.

3. Centers for Disease Control and Prevention. Recommendations for the laboratory-based detection of Chlamydia trachomatis and Neisseria gonorrhoeae - 2014. MMWR Recomm Rep. 2014;63 (RR-02):1-19.

4. Workowski KA, Berman S; Centers for Disease Control and Prevention. Sexually transmitted diseases treatment guidelines, 2010. MMWR Recomm Rep. 2010;59(RR-12):1-110.

5. Choroszy-Król I, Frej-Mądrzak M, Jama-Kmiecik A, Bober T, Sarowska J. Characteristics of the Chlamydia trachomatis species: Immunopathology and infections. Adv Clin Exp Med. 2012;21(6):799-808.

6. Frej-Mądrzak M, Krzemińska I, Choroszy-Król I. Zakażenia chlamydialne u dzieci. Forum Zakażeń. 2011;2(3):41-44.

7. Wilkowska-Trojniel M. Udział zakażenia Chlamydia trachomatis w niepowodzeniach ciążowych u kobiet w regionie północno-wschodniej Polski. Akademia Medyczna w Białymstoku, Poland; 2007.

8. World Health Organization. Global Strategy for the Prevention and Control of Sexually Transmitted Infections: 2006-2015. WHO; 2007. http://www.who.int/hiv/pub/toolkits/stis_strategy\%5B1\%5Den.pdf.

9. Nitsch-Osuch A, Wardyn KA, Choroszy-Król I. Zakażenia wywołane patogenami atypowymi w praktyce lekarskiej. Wrocław, Poland: Górnicki Wydawnictwo Medyczne; 2007:11-22.

10. Pawlikowska M, Deptuła W. Choroby u ludzi spowodowane chlamydiami i chlamydofilami. Postepy Hig Med Dosw. 2007;61:708-717.

11. Frej-Mądrzak M, Teryks-Wołyniec D, Jama-Kmiecik A, Sarowska J, Gosciniak G, Choroszy-Król I. Zakażenia układu moczowo-płciowego oraz spojówek Chlamydia trachomatis u dorosłych i dzieci w latach 2012-2013. Family Medicine \& Primary Care Review. 2014;16(3):225-227.

12. Di Bartolomeo S, Mirta DH, Janer M, et al. Incidence of Chlamydia trachomatis and other potential pathogens in neonatal conjunctivitis. Int J Infect Dis. 2001;5(3):139-143. 
13. Khoshdel A, Taheri S, Khadivi R, et al. Incidence and bacteriological profile of neonatal conjunctivitis in Hajar Hospital, Shahrekord, Iran. Iran J Pathol. 2012;7(2):86-91.

14. Bekler C, Kultursay N, Ozacar T, Sayiner A, Yalaz M, Akisu M. Chlamydial infections in term and preterm neonates. Jpn J Infect Dis. 2012;65:1-6.

15. Yu J, Wu S, Li F, Hu L. Vertical transmission of Chlamydia trachomatis in Chongqing, China. Curr Microbiol. 2009;58(4):315-320. 